\title{
Reflexión-meditación cristiana sobre el terremoto
}

\author{
Jon Sobrino S. J.*
}

\begin{abstract}
Resumen
Esta reflexión nos permite conocer la verdad histórica y humana - conocimiento que es fundamental para la fe, aunque hoy día estemos asistiendo a su deshistorización-y la verdad de Dios. Un terremoto crucifica a su manera, pero ante todo muestra la vulnerabilidad mayor y englobante de los pobres. Ante estos hechos, es normal que en una catástrofe las personas se remitan a Dios, es decir, que en Él se busque algún "sentido" para que el terremoto no exprese sólo muerte, destrucción y absurdo. ¿"Dónde estaba Dios"? "Dios estaba en el terremoto manteniendo la esperanza". Es la esperanza que siempre mantuvo monseñor Romero y que siempre ofreció a los demás. En estos días resuenan sus palabras: "Sobre estas ruinas brillará la gloria del Señor".
\end{abstract}

Un terremoto da qué pensar, y ojalá éste desencadene muchas reflexiones, cada una de ellas con su aporte específico. La reflexión cristiana puede ofrecer una perspectiva global, en la cual se pueden y deben integrar otras reflexiones, y ofrece sobre todo una perspectiva parcial: hacer central a las víctimas para comprender lo ocurrido y reaccionar adecuadamente'.
Este enfoque globalizante y parcial es quizás lo más importante que tiene que ofrecer la fe. Pero necesita una aclaración, pues en la conciencia colectiva y en momentos de catástrofes naturales $l o$ cristiano se suele comprender ciertamente como exigencia de ayuda a damnificados, pero quizás más específicamente aún como momento para recurrir a Dios. En países de religiosidad masiva,

* Director del Centro Pastoral y Director del Centro Monseñor Romero de la Universidad Centroamericana "José Simeón Cañas".

1. Un primer esbozo de este artículo apareció en Carta a las iglesias 466, 16-31 de enero de 200)1. p. 10-14. 
como El Salvador, es normal que en una catástrofe las personas se remilan a Dios como al referente decisivo y superior a cualquier otro. A Dios hay que pedir perdón y aplacar, y, por otra parte, en él se puede encontrar clemencia, protección y esperanza. Es decir, en Dios se busca algún "sentido" para que el terremoto no exprese sólo muerte, destrucción y absurdo.

A veces, sin embargo, no es así, y entonces Dios es cuestionado y puede salir malparado por no impedir las catástrofes. Ejemplo clásico es el terremoto de 1755, que destruyó la ciudad de Lisboa, lo que llevó a Voltaire a agrias reflexiones sobre Dios $^{2}$. Y tampoco hay que extrañarse de ello, pues para el creyente, ante catástrofes, naturales o históricas, es inevitable tener que habérselas con el Dios en quien cree, quien, al parecer, no puede o no quiere evitarlas. Es el problema conocido como teodicea: cómo justificar a Dios ante las víctimas. La tarea se ha intentado muchas veces y de diversas formas. Encontrar una solución ha resultado ser tarea difícil, sino imposible.

Todo esto lleva a preguntamos con seriedad “dónde estaba Dios en el terremoto", lo cual analizaremos al final de este artículo. Pero, a pesar de la gravedad de la pregunta, no vamos a comenzar nuestra reflexión cristiana por ahí, sino por lo que ésta hace ver de la verdad del terremoto y de la verdad de los seres humanos. Y csic querer conocer la verdad histórica y humana — no sólo la verdad de Dios- le es igualmente esencial a dicha $\mathrm{fe}$, aunque en nuestros días estamos asistiendo a su deshistorización.

En la tradición de Jesús de Nazaret, sin embargo, tal como ha llegado hasta nosotros de la mano de Medellín, de Monseñor Romero, de Ignacio Ellacuría, la fe no debe ser deshistorizada, sino lodo lo contrario. Lo cristiano no es distanciamiento, sino profundización en lo humano. No es desapego, sino dejarse afectar por lo que son y sufren los humanos - las víctimas del terremoto-, y también por sus esperanzas. Desde este apego a lo histórico queremos analizar la realidad que revela el terremoto - de inmenso pecado y de gracia indefensa-. Y quizás note el lector que también dejamos aflorar el sentimiento. En concreto, la indig- nación de que en las catástrofes siempre es "lo mismo" y sufren "los mismos"; la esperanza de que algún día no sea así; y una especie de veneración ante la vida de los pobres, antes, durante y después de las catástrofes. Por último - y esto ya es específicamente cristiano-, ojalá veamos en las víctimas un sacramento del Dios escondido.

Hemos comenzado relacionando el terremoto con Dios - y con crudeza-, a pesar de que no vamos a tratar de ello ahora, sino sólo al final. Lo hemos hecho para que no se piense que una reflexión, por ser cristiana, puede ofrecer explicaciones y recetas fáciles ante el desastre y sinsentido de un terremoto, como si, apelando simplemente a Dios, la fe y la reflexión no participasen de la indefensión de lo humano ante las calástrofes, sean éstas naturales o históricas. Esto sería la fe barata, hermana de la gracia barata que denunciaba Bonhoeffer. Pero, aunque sin ol:ecer recetas, pensamos que la fe cristiana puede aportar luz para comprender el terremoto y reaccionar ante él.

$Y$ para terminar esta introducción, de sobra está decir que la fe cristiana no sustituye a otras reflexiones, como las que se hacen en este número monográfico y muchas olras, lodas ellas necesarias. Más bien las anima y encuentra en ellas base y fundamento para expresarse como fe histórica y poder determinar, en términos históricos, lo que es gracia y pecado, dónde está Dios y dónde están los idolos.

\section{Una perspectiva integral y parcial}

Primera proposición. Las catástrofes naturales suelen ser tratadas desde una perspectiva que, con frecuencia, peca de reducida y de encubridora. Lo cristiano puede ayudar a superar ambas cosas.

En la historia se ha ido afinando la comprensión de las catástrofes naturales y de qué hacer ante ellas. En la actualidad, trabajan en ello instituciones internacionales, como Naciones Unidas, el Banco Mundial, instituciones gubernamentales, iglesias, organizaciones no gubernamentales. En conjunto, sin embargo, simplificando las cosas, operativamente sigue prevaleciendo la idea de que

2. "Si el último recurso que nos resta para disculpar a Dios es confesar que su poder no ha podido triunfar del mal físico y moral, ciertamente prefiero adorarlo como limitado antes que como malvado", citado en J. A. Estrada. La imposible teodicea (Madrid, 1997) p. 212. Otros han llegado a decir que "la única justificación de Dios es que no existe". 
un terremoto es una catástrofe natural, que causa ingentes daños físicos, además de otros personales y psicológicos, ante el cual hay que reaccionar con ayuda inmediata para paliar sufrimientos básicos, y con ayuda extraordinaria - normalmente de la comunidad internacional- para la re-construcción. A esto se suelen añadir declaraciones de la necesidad de estudiar los riesgos para el futuro. Pero a medida que avanza la ciencia y la conciencia de la co-responsabilidad dentro de la familia humana, esta visión tradicional muestra limitaciones y peligros, que es necesario poner al descubierto y superar. A ello puede ayudar lo que llamamos la "perspectiva cristiana".

Qué es lo fundamental ya lo hemos dicho: hacer central en la realidad al pobre y a la víctima; ver y juzgar desde ellos la verdad de lo que ocurre antes, durante y después de una catástrofe; exigir una reacción última de compasión y juslicia; denunciar a los responsables de la pobreza y la injusticia; por último - indefensamente-, ofrecer una esperanza, reafirmada por una misteriosa fe en Dios. A niveles más ideológicos, por así decirlo, lo suyo es relacionar naturaleza e historia, historia y responsabilidad humana, y hacer de la realidad histórica -de pobres y víctimas- sacramento de Dios. Según esto, analicemos el terremoto desde la perspectiva cristiana.

\subsection{Catástrofe " $y$ " radiografia del país}

El terremoto es una catástrofe, pero es además portador de verdad. Es una radiografía del país, en sus diversas dimensiones: física, económica, social, política y religiosa. Como los rayos $\mathrm{X}$, muestra la verdad oculta que se quiere que pase desapercibida. Hoy sabemos — podemos saber- del país más que antes del terremoto, aunque pronto se intentará encubrir, en parte al menos, ese nuevo y más adecuado saber.

Esa realidad es, en lo fundamental, la pobreza y la vulnerabilidad de la sociedad salvadoreña, producto, en lo sustancial, de la injusticia y de una conducción del país que no hace de su eliminación lo central. Esa realidad es "conocida", ciertamente, por quienes la sufren y padecen, pero no es "reconocida" eficazmente por los poderosos, den-

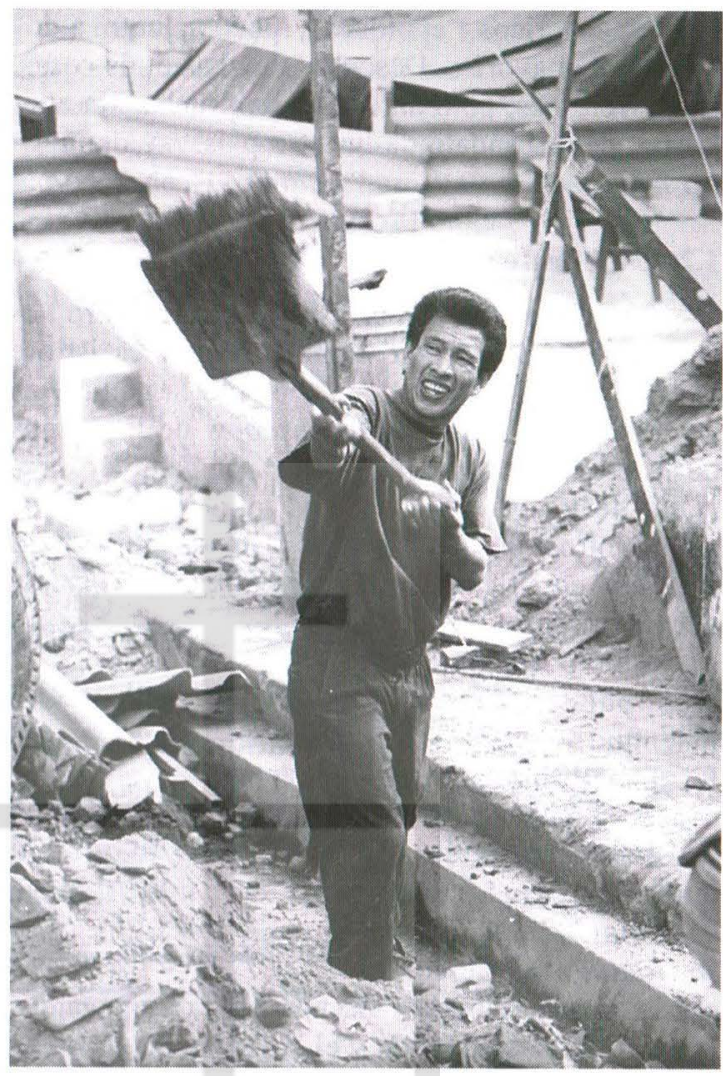

tro y fuera del país'. Ante la catástrofe, éstos reaccionan en alguna medida, pero en lo fundamental no suelen guiar su actuación de acuerdo a la verdad que pone de manifiesto el terremolo. Por eso, hay que insistir en que este fenómeno no es sólo tragedia, sino que tiene un inmenso potencial "epistemológico", de dar a conocer la realidad, y un inmenso potencial educativo para introducir en la verdad a todo el que "ama la verdad".

En esto insiste la fe cristiana. El terremoto muestra la verdad de la realidad y la desenmascara como escándalo fundamental. Incluso antes de preguntarse por justicia e injusticia, pone en palabra realidades y sentimiento primarios: el inicuo agravio comparativo entre seres humanos, hijos e hijas de Dios, y la vergüenza que debemos sentir los seres humanos ante ello. El terremoto es la escenificación trágica de la parábola de Jesús: co-

3. Monseñor Romero decía que sus homilias querían ser "voz de los sin voz". A lo cual añadía algo que ha pasado más desapercibido: "por eso caen mal a los que tienen demasiada voz". Pues bien, "Ios que no tienen voz" son los que "conocen la realidad" y "los que tienen demasiada voz" son "los que no quieren reconocerla". 
existen los ricos "epulones", pocos, junto a los "lázaros", mayorias. Descubre muchas otras cosas, como veremos, pero ante todo da prueba, sin apelación, del escándalo de nuestro país -y de nuestro mundo-.

\subsection{Catástrofe natural "e" histórica}

El terremoto es una catástrofe natural, pero tiene que ser considerado también como catástrofe histórica y social ${ }^{4}$. Es decir, no sólo la naturaleza (o Dios) son causas y responsables de los daños de la catástrofe, sino que éstos son también producto de lo que nos hacemos los seres humanos unos a otros, de cómo hemos ido configurando la realidad en "tiempos de normalidad". Más específicamente, es producto de lo que no hacemos para prevenir la magnitud de la catástrofe, ni para aminorar sus consecuencias. Y la tragedia aumenta en el posterremoto, cuando la ayuda y la solidaridad no son manejadas de forma
El terremoto es una catástrofe, pero es además portador de verdad. Es una radiografía del país, en sus diversas dimensiones: física, económica, social, política y religiosa. siendo hoy la pregunta fundamental que la fe cristiana dirige a todos, y muy directamente a quienes configuran la sociedad: el capital, los gobernantes, los políticos, los militares, los eclesiásticos...

\subsection{Ayuda "y" solidaridad}

La ayuda es necesaria, pero para ser humana y eficaz debe llevarse a cabo como solidaridad, lo cual no es lo mismo. Más aún, es bien sabido cómo la ayuda, entendida como reacción quasimecánica y unidireccional, en particular en el nivel oficial e internacional, puede ser un modo de Iranquilizar conciencias, de mantener control social y, sobre todo, de evadir responsabilidades de justicia. Es la coartada para no tener que enfrentarse con lo que verdaderamente exige una catástrofe: la solidaridad.

Ayuda es dar de lo que uno tiene para aliviar el sufrimiento ajeno $-y$ eso es bueno, necesario y urgente-. Pero la solidaridad va más allá, y caer en la cuenta de ello es eficaz, y, peor aún, cuando aparece la propaganda, la mentira, la corrupción y el latrocinio.

La consideración del terremoto como catástrofe también histórica y social es un cambio de perspectiva decisivo. Lleva a exigir responsabilidades (lo que los ilustrados hacían antes con Dios), y con la gravedad que entraña el caso, a no encontrar escapatoria en la naturaleza y a no disimular la irresponsabilidad con ayudas de emergencia.

Volvamos a la fe cristiana. Si a la tradición democrática le es esencial que los responsables tengan que rendir cuentas - también ante las catástrofes naturales-, la tradición cristiana es más radical. En su origen está la gran pregunta que no admite escapatoria: “qué has hecho de tu hermano?". Esa pregunta de Dios a Caín es antropológica y socialmente fundante, pues en la Biblia el asesinato de Abel - no sólo el pecado de Adán y Eva, como suele pensarse - tiene rango de pecado "original", originante. Ante las víclimas, ésa sigue importante no sólo para crecer en finura humana, sino para ayudar - también en un terremoto- eficazmente, y no sólo a medias. La solidaridad implica ante todo dejarse afectar por el sufrimiento de otros seres humanos, compartir el dolor y la tragedia, lo cual $-\mathrm{y}$ no consideraciones a priori, políticas, ideológicas, partidistas, religiosas- es lo que debe guiar la ayuda. Implica ayudarse mutuamente los que dan y los que reciben. Hay que dar no sólo según el criterio del donante, sino teniendo también en cuenta a quien recibe. Y sobre todo hay que dar, estando abiertos a recibir - aunque no sea más que el anhelo de vivir que lienen las víctimas, su dignidad, creatividad y esperanza muchas veces- y a recibir con el gozo de saberse y hasta de sentirse miembros de una misma familia humana. Implica no poner límites en el tiempo a la "ayuda". "Solidarity? For ever". "Solidaridad? Para siempre". como he escuchado en comités de solidaridad con El Salvador en Estados Unidos. Implica mantener la prioridad de construir lo

4. Y sc van dando pasos en csa dirccción. Con ocasión del terremoto del 26 de cncro, una publicación de Oxfam describe a India como "uno de los mayores teatros de la tragedia, tanto natural como provocada por el hombre". Scgún los analistas, los gobicrnos ponen más ćnfasis en socorrer a los damnificados que cn prevenir las calástrofes, Henar L. Scnovilla, Vida Nueva 2267,3 de febrero de 2001 , p. 3.3. 
humano, personas, comunidades, pueblos, a cuyo servicio habrá que construir obras físicas, pero no a la inversa. Necesario es reconstruir casas, escuelas y alcaldias, también templos, pero más necesario es ayudar a la construcción de comunidades y pueblos. Necesario es reparar caminos, pero más necesario es ayudar a encontrar modos verdaderos de caminar en la vida.

En la tradición cristiana, para Pablo es esencial "Ilevarse mutuamente"; para Miqueas, "caminar con rectitud, en justicia y ternura"; para Jesús, "el celebrar la mesa compartida". Estos son presupuestos y horizontes, a la vez, de que la ayuda se convierta en solidaridad humana: el "unos junto con otros", el "siempre del caminar", "la fraternidad entre desiguales".

\subsection{Reconstrucción "y" construcción}

La re-construcción de lo que ha caído es necesaria, pero debe estar guiada por la construcción de lo que todavía no ha existido. Entre nosotros no se trata de "re-construir" el viejo El Salvador, en el cual cada diez años una u otra parte del país quedará destruida. Se trata de construir un El Salvador nuevo, y en esto hay más que un juego de palabras o ingenuidad pueril aunque si hay utopía-. Hay que dar pasos realistas para re-construir, pero sin el horizonte del construir lo nuevo todo seguirá sustancialmente igual: pobreza, desprecio del pobre, inicua desigualdad, injusticia, mentira y encubrimiento.

Re-construir y construir exigen dinamismos

El terremoto es una catástrofe natural, pero tiene que ser considerado también como catástrofe histórica y social. Es decir, no sólo la naturaleza (o Dios) es causa y responsable de los daños de la catástrofe, sino que éstos también son producto de lo que nos hacemos los seres humanos unos a otros, y místicas diferentes, y hay que ser conscientes de qué dinamismo y de qué mística se quieren imbuir las tareas después de las catástrofes. Para re-construir puede bastar la ayuda - aunque tenga que ser voluminosa-, pero para construir es necesaria otra cosa. Cualitativamente, se necesita una voluntad humana, social, política- para revertir la historia de un país - y del planeta humano- Cuantitativamente, se necesita que la comunidad inlemacional tome la decisión - por fin- de hacer posible la vida en el planeta, ciertamente, en países como El Salvador, Honduras, India, Los Grandes Lagos...
Si queremos que la familia humana sobreviva se necesita mucho más que la ayuda, la que - cicateramente y en descenso- dan los países ricos. Se necesita conversión antropológica y social a la primariedad de "la familia humana", superar la idea de la nación, el continente, el bloque, como centro absoluto e indiscutible del interés egocéntrico y egoísta. Se necesita la voluntad de un "plan Marshall", por la magnitud y envergadura de la ayuda, y también por su finalidad. Hace medio siglo se comprendió muy bien que, si no se construía una nueva Europa, peligraba todo el mundo occidental. De la necesidad se hizo virtud y Alemania resurgió de las cenizas. Necesidad o utopía, hay que construir un mundo nuevo, no simplemente re-construir el antiguo. Si no se "construye" el tercer mundo, peligra todo el planeta.

La tradición cristiana es experta en esa ulopía: "He aquí que yo creo cielos nuevos y tierra nueva, y no serán mentados los primeros ni vendrán a la memoria... Edificarán casas y las habitarán, plantarán vin̄as y comerán su fruto. No edificarán para que otro habite, no plantarán para que otro coma" (Is $65,17.21 \mathrm{~s}$ ), decía la escuela de Isaías siglos antes de Cristo. Y el Nuevo Testamento termina: "Vi una nueva tierra y un nuevo cielo" (Ap 21, 1). Es la ulopía, la mística de lo juslo y de lo nuevo.

Lo que acabamos de decir sobre el terremoto como portador de verdad, sobre la responsabilidad (en buena parte) histórica en la catástrofe, sobre la ayuda que debe convertirse en solidaridad, sobre la utopía de un mundo nuevo, no sólo remendado, son cosas necesarias para abordar el terremoto. Expresan una visión cristiana de las cosas y pucden ser compartidas, más o menos, por otros. Indudablemente, deben ser historizadas por instituciones y saberes, en sus dimensiones técnicas, legales, psicológicas, educativas, políticas. La visión cristiana es débil sin el concurso de otros. Sin embargo, la creemos útil, porque abre a áreas de la realidad que quedan desatendidas en la visión convencional. $Y$, en cualquier caso, porque en su centro está algo fundamental para la vida de la familia humana, que todavía no hemos mencionado. 


\subsection{Víctimas "y" sacramentos de Dios}

Desde la fe cristiana, tal como la actualizaron entre nosotros Monseñor Romero y el padre Ellacuría, las víctimas son más que víctimas. Son "el pueblo crucificado", "el siervo doliente de Yahvé", "el Cristo crucificado de nuestro tiempo". Estas víctimas imponen absoluto respeto y silencio reverencial, pero ante ellas quizás podamos decir además - con fe y balbuceos-que son la presencia de Dios en el terremoto, Dios escondido, crucificado, solidario.

Bien sea en este lenguaje teologal, de fe, bien sea en cualquier otro lenguaje humano, es decisivo ver a las víctimas con respeto, devoción y veneración, pues nos ponen ante el misterio de la realidad. Quizás puedan remitirnos también al misterio de Dios, el impensado, que —en su escondidez y ocultación- sigue siendo fuente de promesa y esperanza. En cualquier caso, si algo no hay que hacer con las víctimas es reducirlas a objetos - ni siquiera a objetos de ayuda-. Son signos y sacramentos de una realidad misteriosa, la de Dios, que participa en sus sufrimientos.

2. La revelación de la realidad que se quiere encubrir

Segunda proposición. El terremoto dice una palabra sobre la realidad del país y lo hace en forma de clamor. Escuchar ese clamor es exigencia e invitación a los seres humanos a superar la tentación innata de oprimir la verdad y a ser honrados con la realidad.

Desde la tradición cristiana, la reacción más inmediata ante un terremoto es, sin duda, la misericordia, la ayuda a las víctimas, como lo ejemplifica la parábola del buen samaritano. Pero hay que reaccionar también escuchando la palabra que dice el terremolo, la verdad que expresa y la mentira que desenmascara. En esto queremos detenernos ahora, porque no suele tenerse muy en cuenta. Sin embargo, es absolutamente necesario para ser seres humanos, "que aman la verdad", y no la trivializan, y para "construir" una sociedad nueva y no sólo remendar la antigua.

Para quien tenga ojos para ver el terremoto, lleva a conocer mejor la verdad del país, como lo explica con toda claridad el pronunciamiento de la UCA Dicho esto en lenguaje existencial, puede iluminar nuestra propia verdad como seres humanos: ¿qué somos?, ¿víctimas, victimarios, damnificados, inmunes, intocables, insensibles, volcados a los demás? Y puede llevar también a conocer no sólo la maldad, sino también la bondad, cosas ambas que se quieren ocultar. Lo primero es evidente, pero también se quiere encubrir lo segundo, y a veces con mayor denuedo, pues la bondad desenmascara la maldad, como la luz disipa las tinieblas. No hay otra explicación para el olvido que los poderosos de este mundo han decretado sobre monseñor Romero, por ejemplo, en los últimos veinte años. No se quiere que se conozca lo bueno de la realidad salvadoreña.

Prueba de esto es que en liempos de catástrofe oficialmente se habla, incluso se hace propaganda de acciones heroicas y conmovedoras, pero no se habla de otras "bondades": crecimiento en conciencia social, en demandas y protestas, en conciencia de comunidad para superar enfoques individualistas, en conciencia de lo local contra la omnipresencia, la centralización y la prepotencia estatal". Estas "bondades" se quieren ocultar, reduciendo la bondad a anécdotas conmovedoras. Controlar el lenguaje ha sido desde siempre un modo importante para encubrir.

Ante un terremoto hay que rcaccionar, pues, con misericordia, por supuesto, pero también con afán de verdad y con honradez con lo real. Y para ello hay que hacer contracorriente. Vivimos en una cultura que no es sólo cultura de la violencia y de la muerte - como suele admitirse-, sino que es también cultura de propaganda, mentira y encubrimiento, lo cual pasa más desapercibido. Los po-

5. La reacción popular y social después del terremolo de Mćxico es un claro cjemplo. Piensan algunos que fuc cl principio del final del Parlido Revolucionario Institucional. 
bres y las víctimas conocen la verdad de su mundo y del nuestro, pero en la conciencia colectiva se introyecta la ignorancia y el no saber. Los que saben "disimulan" la verdad, comunicándola en dosis, no en su totalidad y tragedia. La "controlan" en los medios, ahogando verdades Irágicas en medio de miles de horas de entretenimiento, música, deporte, sustituyendo la gravedad de la realidad por el sensacionalismo del dinero de los poderosos o la vida de los famosos. A veces la "reprimen", simplemente, con la mentira. Y el resultado final es que la "encubren": por lo que se dice y por lo que no se dice, la realidad más real pasa desapercibida ${ }^{6}$.

Nunca se tuvieron tantos conocimientos sobre la realidad de nuestro mundo: pobreza y despilfarro, enfermedad y lujo, gastos en armas, corrupción gubernamental. Pero puesto todo esto junto, no se acaba de reconocer la verdad de este mundo. En estos días de terremoto, junto a verdades inocultables por su naturaleza, casas derruidas, deslaves, se sigue ocultando la verdad más profunda de lo ocurrido y sus causas. Se miente cuando es necesario - hasta el número de muertos se ha deseado ocultar-, se argumenta estrafalariamente para dejar en alto el buen nombre de instituciones, se mantiene -con excepciones- silencio por parte de partidos, incluso de algunas universidades e iglesias. Y lo más grave y fundamental: se oculta una historia secular de capitalismo, que ha hecho de El Salvador un país pobre, vulnerable, injusto.

$\mathrm{Y}$ aqui es donde la fe cristiana tiene algo importante que decir. El ser humano, capaz del bien, es también proclive al mal, al pecado. La esencia del pecado consiste en "dar muerte", y en diversas formas: asesinar, empobrecer, agraviar, ofender. De ahí que en la teología de Juan, "el Maligno es asesino". Pero al pecado de dar muerte lo acom- paña, como por necesidad, el pecado de encubrir, de "mentir", y de ahí que el Maligno sea asesino y "mentiroso", y que la violación del octavo mandamiento (no mentir, no encubrir) siga, como por necesidad, a la violación de los mandamientos que defienden la vida: no robar, no matar.

"Oprimir la verdad con la injusticia", dice Pablo, es pecado fundante del ser humano, y esa pecaminosidad está actuante en personas, pero también en instituciones, culturas y sistemas políticos. Es evidente, entre nosotros y en Estados Unidos, que la democracia no ha suprimido la mentira, ni el encubrimiento, y que los teólogos del neoliberalismo no han suprimido la tergiversación de la verdad'. Entonces, así como Medellín denunció que existe la injusticia estructural y la violencia institucionalizada, hay que denunciar con fuerza que existe la mentira institucionalizada. Con ella hay que contar siempre, y también en tiempo de terremoto.

A esa mentira, la fe cristiana opone, como algo central, la verdad. A la realidad encubierta opone la realidad que se manifiesta. La realidad —digámoslo así- no es muda, sino que está en favor de la verdad. "La realidad quiere tomar la palabra", dice Karl Rahner, en forma de tesis metafísica para expresar la dimensión simbólica de la realidad: ésta quiere "expresarse". En palabras más conocidas, el concilio Vaticano II dice que en la realidad hay "signos de los tiempos", en los cuales se hace presente la verdad que caracteriza a una época (Gaudium et Spes, 4) - y en los que se hace presente el mismo Dios (11) - Y eso es así desde el comienzo de la tradición bíblico cristiana. En su momento fundante, la realidad pronuncia su verdad a través de una palabra. Y como esa realidad es sufrimiento y opresión, la palabra toma la forma de un clamor: "He escuchado los clamores de mi pueblo" (Ex 3, 7), dice Dios. Es el momento

6. Tres ejemplos que hemos oído cstos días. Se crilica al gobierno por comprar armas por 60 millones de dólares en tiempos de terremoto, pero no se menciona al gobicrno o a los gobicrnos que han hecho un gran negocio al venderlas. "Sigue valiendo más, informalivamente hablando, un blanco sccuestrado que 10000 congoleños torturados o asesinados", dice Gcrardo Gonzálcz Calvo, dircetor-jefe de Mundo Negro. En un partido de fútbol - jugado, por coincidencia el $13 \mathrm{de}$ febrero, día del segundo terremoto- entre el Madrid y el Lazio, cl valor de los 22 jugadores sobre el campo cra, a precio de mercado, de 125000 milloncs de pesctas, unos 650 milloncs de dólares. No se dice que esa cifra puede ser parte importante del presupucsto nacional de un país del África negra.

7. Michacl Novak compara a las multinacionales con el siervo sufriente de Yahvé. Y M. Camdessus habla de la banca mundial como cl ungido de Lucas 4,1 ss, cnviado a anunciar la buena nucva a los pobres. 
fundante de la revelación de Dios, de la fe yahvista y de la constitución del pueblo de Israel.

También en los mejores momentos de la fe en América Latina, la realidad ha tomado la palabra y lo ha hecho en forma de clamor. Al analizar la realidad del continente, comienza Medellín, en 1968: "Esa, miseria, como hecho colectivo, es una injusticia que clama al cielo" (Justicia, 1). Y Puebla, en 1979, dice: "La Conferencia de Medellin apuntaba ya, hace poco más de diez años, la comprobación de este hecho: 'Un sordo clamor brota de millones de hombres, pidiendo a sus pastores una liberación que nos les llega de ninguna parte"' (Pobreza de la Iglesia, 2). El clamor pudo haber parecido sordo en ese entonces. Ahora es claro, creciente, impetuoso y, en ocasiones, amenazante" (88s.).

Si así es la realidad, el ser humano se constituye - dicho metafísicamente- como tal al ser "oyente de la palabra", según la conocida lesis de Karl Rahner. En lenguaje del concilio, debe "escrutar" los signos de los tiempos. Acceder a la realidad es escuchar la palabra que la realidad quiere expresar. De escuchar o no esa palabra dependerá una correcta interpretación de la realidad, pero dependerá también una correcta realización de nuestro ser humano. Ser "oyentes de la palabra" no es algo optativo. Si el ser humano decide escucharla -y responder a ella-, se coloca en camino hacia su propia humanización. Si decide no escucharla, desecharla, ha tomado una opción primordial hacia su propia deshumanización. Por el conlrario, llegar a ser humano es, en definitiva, dar voz a esa palabra de la realidad y responder a ella.

Esta gran intuición de la fe cristiana queda muchas veces desmentida por la historia. Los seres humanos no queremos escuchar la palabra de la realidad, sino que la encubrimos. $Y$ entonces surge la angustia que, parafraseando a Pablo, podemos formular: “qquién nos liberará de este mundo de mentira?". O parafraseando a Antonio Montesinos, “¿quién nos despertará de sueño tan letárgico en que estamos dormidos?".

Quizás nos hemos alargado excesivamente en exponer esta idea. Es sencilla, pero no se toma en serio. Quizás un terremoto pueda ayudar a despertar y a liberamos de la mentira, a mostrar la verdad del país con una fuerza tal que aquélla se haga inocultable. Pero ante el empecinamiento humano -de los poderosos sobre todo- de no querer ver la'verdad de la realidad, vienen a la mente las pa- labras con que termina la parábola de Epulón y Lázaro: si la pobreza de Lázaro no mueve el corazón, los hermanos de Epulón no se convertirán, "ni aunque un muerto resucite".

Para terminar este apartado recordemos a Ignacio Ellacuría, otro de los grandes olvidados en el país, y también encubierto cuando sólo se recuerda de él selectivamente lo que interesa a la antigua izquierda o a los pragmáticos de siempre. Con total convicción hablaba de la verdad de la realidad, de la necesidad de conocerla y de la dificultad de llegarla a conocer. Impactado por la mentira de los poderosos, locales y de las naciones, indignado por su ceguera culpable, trabajó denodadamente por llegar a conocer la realidad y por darla a conocer, hasta el punto de afirmar que la materia fundamental que hay que enseñar en la UCA es la realidad nacional.

Eso es sabido - al menos repelido-y algunos lo recordarán. Lo que quizás haya caído en el olvido, y no por casualidad, es que - sin abandonar los métodos científicos de conocimiento, por supuesto-, en último término, Ellacuría apeló a la tradición cristiana para ofrecer un mélodo eficaz para llegar a conocer la verdad: mirar al siervo sufriente de Yahvé, tal como lo presenta Isaías 52 53, destrozado por la catástrofe histórica que producen los poderosos. "Por lo que producimos sabemos lo que somos", decía. "Mirando al siervo destrozado sabremos la verdad del mundo que lo produce". $Y$ además de esta reflexión bỉblico histórica, usó dos metáforas que, en su día, hicieron historia. "Si el primer mundo quiere saber lo que es que mire al tercer mundo, y allí se verá desfigurado, como en un espejo invertido, en su verdadera figura". La otra metáfora es más fuerte. "Si el paciente - el primer mundo- quiere saber cómo está su salud que haga un examen de heces -el coproanálisis-. Las heces que produce es la pobreza del tercer mundo". Y eso vale para los "primeros mundos locales", dentro de nuestros países.

El terremoto nos puede liberar de la mentira y del encubrimiento. Eso es lo que queremos analizar a continuación. Dicho en terminología crisliana clásica, el terremoto es una palabra sobre el pecado y sobre la gracia en el país. Comencemos por el pecido.

3. El pecado del país: pobreza, engaño e injusticia estructural

Tercera proposición. El terremoto ha puesto al descubierto el pecado del país: la pobreza, la 
vulnerabilidad; el abismo inicuo entre los pocos ricos y los muchos pobres, expresión de la cultura del desinterés y del desprecio; la prepotencia de los poderosos que se torna en hipocresía. En suma, la injusticia que permea el país.

\subsection{Pobreza y vulnerabilidad}

Las palabras son duras, pero más lo es la realidad. Recuperamos la terminología de injusticia estructural - caída en desuso- porque la masividad, la duración y las causas de los males lo exige. Sin hablar de injusticia y de injusticia estructural no estamos hablando de El Salvador. El terremoto lo ha mostrado de forma específica y concreta. No sólo muestra males y daños, sino totalidades y estructuras. Ha mostrado la permanente precariedad y el riesgo de vivir para las mayorías. En palabras cristianas del olvidado Ellacuría, el signo de los tiempos es "siempre" el pueblo crucificado. Lo que varía es la "forma" de crucifixión.

Y tiene toda la razón. Desde tiempo inmemorial, vivir en este país ha sido siempre una carga muy dura de llevar. Oficialmente, la milad de la población vive en pobreza, grave o extrema. De la otra milad, otra buena mayoría vive con serios agobios y dificultades, todo lo cual se agrava con las catástrofes: terremoto de 1965, el huracán Fifí en 1974, otro terremolo en 1986, hace dos años el Mitch. $Y$ no hay que olvidar doce años de guerra, éxodo masivo y destrucción, más tres años de cruel represión gubernamental antes de la guerra. Lo que ha hecho el terremoto es concrelar y agudizar esa pesada carga ${ }^{x}$ y hacerla más pesada para el futuro, pues sus consecuencias han dañado el aparato productivo, los medios de producción agrícola, y han incrementado despidos y desempleo. Podemos repelir con verdad lo que hemos escrito muchas veces: los pobres son lo que no dan por supuesto es la vida -y después del terremoto menos- $-\mathrm{Y}$ jugando con el imaginario que sugiere el terremoto, podemos decir que, en verdad, los pobres son los que "viven a la intemperie".

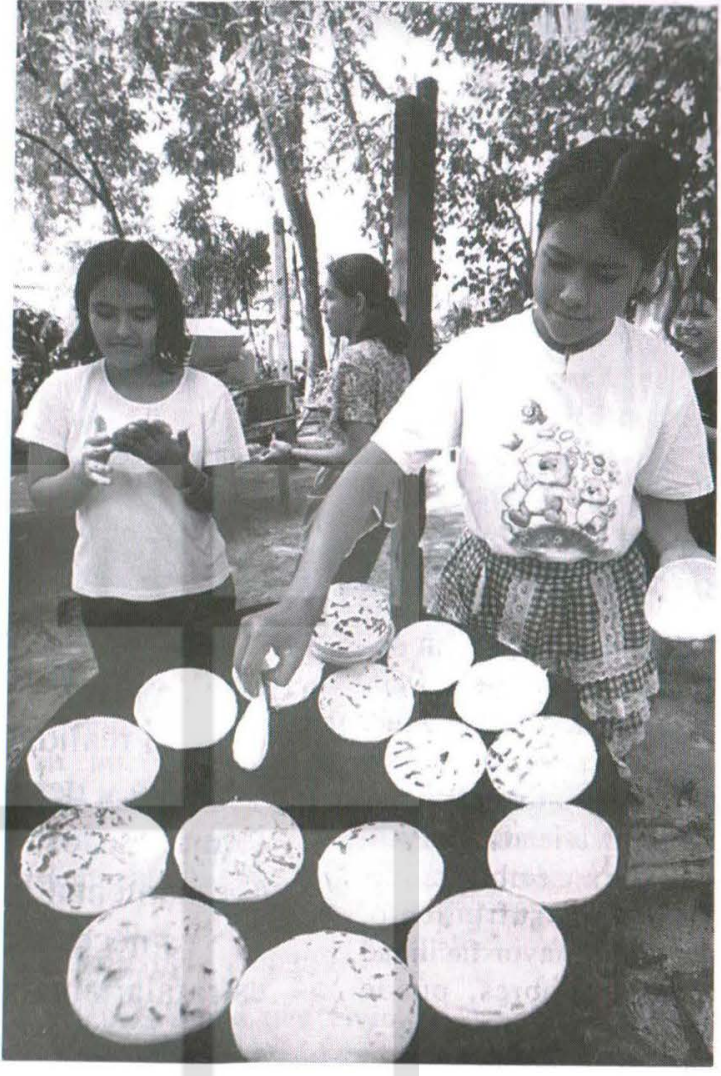

Vivir es, pues, una pesada carga, pero no lo es para todos por igual. Como siempre, lo es mucho más para las mayorias. El terremoto ha destruido casas, pero muy mayoritariamente las de bajareque y adobe, donde viven los pobres, porque no pueden construirlas de cemento y hierro. Los derrumbes han soterrado personas y viviendas -esta vez lambién casitas de clase media baja-, pero normalmente soterran a los pobres, porque muchas veces sólo en inhóspilas laderas han encontrado lugar para sembrar. Muy mayoritariamente mueren los pobres, quedan soterrados los pobres, tienen que salir corriendo con las cuatro cosas que les quedan los pobres, duermen a la intemperie los pobres, no pueden faltar al trabajo los pobres, no encuentran créditos los pobres, se angustian por el

8. Según datos oficialcs provisionales del $15 \mathrm{de}$ febrero, los terremolos han ocasionado I 159 mucrios, 7538 heridos, 37 desaparecidos, 1452608 damnilicados, 68777 cvacuados, 106 hospilales y centros de salud dañados, 286471 viviendas destruidas o dañadas, 16150 derrumbres, 1179 cdificios públicos dañados, 1597 cscuclas dañadas y 91 destruidas, 405 iglesias dañadas o desıruidas, 4.3 muclles dañados. 
futuro los pobres, tienen que emigrar los pobres. $Y$ así sucesivamente. Y lo mismo ocurrió durante el conflicto bélico. La inmensa mayoría de quienes sufrieron la represión y de quienes murieron en la guerra, de uno y otro bando, fueron pobres".

También otros sufren con el terremoto, y a veces gravemente, pues éste ha afectado a dos terceras o tres cuartas partes del país. Además, neoliberalismo y globalización están empobreciendo cada vez más a clases medias en todo el mundo y también en El Salvador. Símbolo macabro de ello fue el soterramiento de casas y personas de clase media en La Colina. Pero esto no quita verdad a la tesis fundamental, según la ley de los grandes números: el sufrimiento masivo es el de los pobres. Otros, por lo general, pasado el susto, pueden encontrar, con dificultad, pero con mayor facilidad que los pobres, medios para subsistir, para encontrar vivienda transitoria, para recibir créditos... Con sufrimiento, pero con mayor facilidad que los pobres, puede volver a la normalidad $y$ pueden seguir viviendo.

$Y$ algunos de ellos, rodeados del lujo de siempre. No es lo mismo el terremoto en la colonia Escalón que en la colonia Guadalupe, como no es lo mismo un terremoto en California o Japón que en Turquía o India.

Como en los derechos humanos, mucho más amenazados los tienen los seres humanos por el hecho de haber nacido en Bangladesh que en Bonn. Dentro de un país sufren los pobres y dentro del concierto de las naciones sufren los países pobres. Sucede - casi- siempre "lo mismo" a "los mismos". "Cambia la forma de crucifixión", decía Ellacuría, pero se mantiene la crucifixión.

$Y$ un terremoto crucifica a su manera. Ante todo, muestra la vulnerabilidad física del país, pero, a través de ella, hace manifiesta la vulnerabilidad mayor y englobante de los pobres. Baste para mosIrarlo el pronunciamiento de la UCA, al cual nos remitimos. Aquí sólo queremos insistir en la tesis fundamental. El Salvador es físicamente, geológicamente, vulnerable, y esto golpea más a los pobres. Lo es económicamente, y el neoliberalismo empobrece más a los pobres, no garantiza el mínimo de vida, ni permite el ahorro. Lo es socialmente, y los pobres son los más indefensos ante los riesgos y las plagas sociales, los fraudes bancarios, el dengue, las diarreas, las bebidas adulteradas... Lo es culturalmente, y los pobres tienen menos recursos para sustraerse a la información y la pseudocultura que se quiere imponer.

La vulnerabilidad afecta a todos, y cada vez más también a las clases medias, como consecuencia del neoliberalismo, que concentra escandalosamente la riqueza. Pero, en su conjunto, no se puede negar que la vulnerabilidad afecta sobre todo a los pobres. Si se me permite decir una trivialidad, un terremolo no se deja guiar por una especie de ojo electrónico, que busca pobres y casas de pobres para destruirlas. Basta con que ocurra en un país estructuralmente pobre y vulnerable como El Salvador y los daños pueden darse por descontado, $y$, por descontado, afectan a los pobres. En este sentido, los terremotos, se parecen a los cementerios: ponen de manifiesto la inicua desigualdad de una sociedad y, así, muestran su más honda verdad. Algunas tumbas son suntuosas, grandes panteones con lujosos mármoles, bien ubicados. Otras, casi sin nombre y sin cruces, se amontonan en lugares marginales y quedan anónimas. Son la mayoría.

El terremoto echa por tierra las casas de los pobres. Eso ocurre a un nivel real, pero también de alto simbolismo. Destruye el hogar físico, que posibilita el hogar real, el núcleo central de la

9. Dicen algunos que haría falta la pluma de Roque Dalton para comunicar con fuerza esta elemental verdad y entonar la letania de los pobres. 
vida. Y muestra la verdad de ese "hogar”. Es más que un juego de palabras decir que al quedar destruidas las pobres paredes exteriores del hogar, dejan al descubierto lo interior de ese hogar: una increíble pobreza. Aparece entonces que los pobres tienen muy poco, muchas veces no tienen nada.

El terremoto ha puesto al descubierto la fragilidad del hogar salvadoreño en su totalidad, y eso - no sólo por quedarse sin techo- es fundamental. El hogar —en griego, oikos - es el símbolo de lo fundamental de la vida. Un terremoto que puede dejar a la cuarta parte de un país sin oikos, sin hogar, muestra que en ese país se peca contra la vida. Muestra también la verdad de la oikonomia (eco-nomía, lo que está en favor del crecimiento del oikos, del hogar), incapaz de asegurar el hogar, la vida. Muestra la trágica situación en que se halla la oikoumene (término que hoy se ha reducido al ámbito intraeclesial, pero que originariamente significaba "todo el orbe habitado", como corresponde a su raíz: oikos: casa). Apunta también a una oikologia (eco-logía), descuidada y a una tierra alrentada, incapaz de acoger maternalmente a los humanos, lo que a su vez facilita la destrucción del terremoto.

Cuando ocurre un terremoto, se derrumba el oikos físico, pero ese derrumbe expresa otro derrumbe mayor: el hogar de la familia humana. Organizaciones internacionales pronosticaban para el año 2000 que dos mil millones de personas vivirían en champas o en casas indignas para seres humanos, con lo cual, a través de la siluación del oikos exterior, denunciaban la tragedia en que vive la familia humana. Y cuando Gustavo Gutiérrez quiere denunciar al mundo de hoy, el del publicitado nuevo milenio, se hace esta sencilla pregunta: "¿dónde dormirán los pobres en el siglo XXI?". Es ilusorio que se apele a las normas de seguridad exigidas en la construcción de viviendas, cuando los pobres no tienen recursos para cumplirlas. Yendo a la raíz, es insultante que no se haya logrado, ni de lejos, vivienda digna para las mayorías, cuando proliferan edificios llamativos y mejoran las autopistas, los hoteles, los aeropuertos. También en El Salvador.

En el terremoto, el oikos, el hogar, se desmorona y desenmascara así la actual ideología de "lo sostenible", como si la economía, la política, el derecho, la sociedad en suma, estuviera construida sobre base firme, y no sobre "bajareque", "adobe", "tierra deslavada". El terremoto muestra trágica y físicamente lo insostenible del todo social.

\subsection{Injusticia y engaño}

Hemos dicho que vivir en El Salvador es una dura carga, pero no lo es para todos por igual. La vulnerabilidad natural es universal, pero sus consecuencias selectivas tienen causas sociales. La tragedia es, pues, en muy buena parte, producto de la injusticia que impera en el país, la cual es expresión y concreción de la injusticia que configura el planeta de forma masiva, cruel y duradera. La Iragedia es, en buena parte, obra de nuestras manos. Simultáneamente, el terremoto hace caer la fachada de cierta prosperidad y verifica - científicamente, es decir, por sus resultados- la verdad de la política neoliberal.

Terminando con años de demagogia postbélica, el terremoto muestra que la sociedad salvadoreña está hondamente dividida, es anlagónica. Se ha caído la fachada de una sociedad que estuviera en buena salud o en camino de conseguirla. Ha mostrado una sociedad de unos pocos con mucho y con muchas posibilidades de recuperación y de muchísimos con muy poco y con muy pocas posibilidades de recuperación. Hace resonar la denuncia del profeta Isaías contra "los que acaparan campo a campo — banco a banco-y dejan sin 
nada a los demás". Por ello, el terremoto muestra también que vivimos en una sociedad que no está reconciliada, y muestra la raíz más profunda de la irreconciliación"'.

En momentos como éstos es cuando viene a la mente el capitalismo en cualquiera de sus formas. Amenaza o da muerte a millones de seres humanos, en el país y en todo el tercer mundo - cada vez más en el primer mundo-. Y perdura en el tiempo, aunque busque maquillar sus resultados. Sigue adelante impertérrito y por una buena razón. El neo-liberalismo no tiene ningún escrúpulo, ni sospecha que genera males, sino que se presenta como buena noticia (Hugo Asmann). "El capitalismo nació sin corazón", dice Adolfo Pérez Esquivel, premio Nobel de la paz. Ha aprendido a vivir sin él y no muestra signos de conversión eficaz, aunque use ahora lenguaje más pulido y confiese sus limitaciones.

Cada diez, quince o veinte años, suele haber catástrofes naturales en el área centroamericana, pero la tragedia que originan no parece enseñar mucho, ni parece servir eficazmente para evitar en lo posible o minimizar la siguiente. Desde el terremoto de 1986 no se ha buscado solución a la situación general de pobreza en el país - problema fundamental-, ni se ha avanzado en prevenir y paliar las consecuencias de catástrofes inevitables. En los quince años entre los dos últimos terremolos, el país ha invertido mucho para mejorar el armamento de la Fuerza Armada y la tecnología de la banca. Pero las casitas siguen siendo endebles, los ingresos familiares de los pobres disminuyen. $Y$ para desescombrar seguimos prácticamente con pico y pala, sobre todo en cantones y aldeas perdidas.
El capitalismo sigue mostrando su voracidad, y el terremoto lo ha mostrado - ejemplarmente- en una tragedia que se ha hecho ya clásica: La Colina. A tiempo, ecólogos y técnicos, salvadoreños y extranjeros, denunciaron el peligro que acarrearía la deforestación de la cordillera del Bálsamo. A tiempo hubo demostraciones y protestas en contra de la construcción de viviendas, en la base de la colina. Haciendo oídos sordos, con la anuencia o el silencio de los tres poderes, ejecutivo, legislativo y judicial, la empresa constructora levantó centenares de casas, y ocurrió lo que tenía que ocurrir: con el terremoto vino el deslave, alrededor de 270 casas quedaron soterradas bajo cuatro metros de tierra y centenares de personas murieron soterradas". Ahora se debate sobre la legalidad o ilegalidad de la consirucción, y se apela a la casuística, tan querida por los poderosos, porque tienen medios para dominarla y salir con bien. A nosotros nos recuerda otra cosa más allá de la casuística. Los grandes males internos de Israel comenzaron con la acumulación, "campo a campo", como hemos dicho. Pero sucedió algo más: a los oligarcas y terratenientes de entonces, se plegaron los jueces, los sacerdotes, los falsos profetas... Como en La Colina.

El terremoto ha quitado la fachada cosmética al sistema. Las promesas de desarrollo sostenible se han venido abajo por lo insostenible de la infraestructura económica del país. Los cantos de sirena de la democracia se han convertido en ruidos desafinados cuando las mayorías son tan absolutamente desiguales ante la ley, y sobre todo ante la vida. La prepotencia de una conducción política que pretende tener las cosas en sus manos también se ha venido abajo ante la impotencia no sólo para preve-

10. Con ocasión de la visita de Juan Pablo II a El Salvador, en 1996, escribimos que nos parecía inadecuado, incluso una trampa, plantear el problema de la reconciliación - y pedir al Papa ayuda para cllo - en términos de superar los odios de la guerra, y no en términos de superar la injusticia cconómica. Eso cs lo que mucstra cl terremolo. Cicrto es que algunos pudientes - de bucn corazón, con mayor o menor convicción- ofrecen ayuda cstos días. Pero cslo no cambia lo sustancial, porque no cambia lo sustancial de sus vidas y de la conducción que imprimen al país. Véase "La preparación de la visila de Juan Pablo II. Breves reflexiones lcológicas", ECA, $567-568$ (1996) pp. 17-28.

11. "Solamente gente extraña explota la naturaleza, destruye los bosques por la tala, deja vacíos los mares por la pesca y no para de un lado a otro como los nómadas. Pcro el que quicre habitar y vivir ahí, cstá intcresado cn la conservación de las bases de su vida y conservará su medio natural capaz de vida. Intentará compensar cualquier intervención en la naturaleza y establecer cl cquilibrio. Los confliclos cconómicos-ccológicos son hoy, en su mayor parte, conflictos entre las grandes empresas extranjeras y los habitantes, conflictos por lo tanto entre los intereses de la explotación por una parte y cl interćs en la habitabilidad de la naturaleza por otra", "Progreso y precipicio. Recuerdos del futuro del mundo moderno", Isidorianum 9 (2000) pp. 310-311. 
nir la magnitud de los daños, sino para manejar las ayudas y sobre todo para mirar al futuro. ¿Qué visión de país tienen que ofrecer gobernantes y oligarcas locales, el imperio y la banca intemacional? Por lo que toca al gobiemo descuella su desidia y negligencia. También su protagonismo y empecinamiento. Tres gobiernos de ARENA no han cambiado este panorama. Y el aislamiento del gobierno actual es cada vez mayor.

Tiempos hubo en que se hablaba del pecado, quizás excesivamente, incluso con superficialidad, masoquismo e injusticia. Había muchos pecados, contra Dios y contra la Iglesia, capitales, mortales y veniales. Lutero llamaba al examen de conciencia de esos pecados "carnicería humana", y no le fallaba razón. Bien está, por lo tanto, que haya desaparecido la obsesión y el horror que generaba todo lo que pudiera ser pecado. Lo que pasa es que después, la realidad de pecado desapareció del lenguaje y de la conciencia pública, y eso no es ningún bien.

En épocas de mayor finura espiritual, se tomaba el pecado más en serio, y el salmista pedía a Dios, de buena fe: "del pecado oculto declárame inocente" (Sal 19, 12). Pues bien, el terremoto hace más difícil ocultar el pecado, y eso es esencial a la tradición cristiana. Juan habla del "pecado del mundo", y Pablo habla, en singular, de hamartía, el pecado con su poder. Con mayor sencillez, los sinópticos declaran pecado el dar muerte a Jesús en la cruz. Eso, el dar muerte, el generar víctimas, el cooperar con la muerte de los débiles no ha desaparecido del país ni del planeta. Todo lo contrario. Eso lo ha desenmascarado el terremoto.

\section{La gracia: la santidad primigenia}

Cuarta proposición. El terremoto no sólo revela pecado, sino también gracia. Por ser una realidad límite, puede expresar con vigor la solidaridad de crear familia humana y sobre todo la santidad primordial del vivir.

Es más fácil escribir sobre la tragedia y la maldad que sobre la vida y la bondad. Pero, aunque muy brevemente, digamos que en medio de la tragedia del terremoto la vida sigue pujando, atrayendo y moviendo con fuerza.

\subsection{Crear familia humana}

En tiempos de terremoto suele aparecer compasión, a veces fugaz, a veces rutinaria y hasta hipócrita, pero a veces es muy real, pues proviene de las entrañas, que han sido tocadas por el dolor de las víctimas. Ahora sólo queremos ofrecer algunas reflexiones para que la compasión que lleva a la ayuda produzca creatividad, generosidad $y$, en definitiva, solidaridad, familia humana. Ya lo hemos insinuado antes, en la primera proposición, pero digámoslo en más detalle.

En primer lugar, para construir familia humana es necesario dejarse afectar por la tragedia, no rehuirla ni suavizarla. No se trata de masoquismo, ni de exigir imposibilidades psicológicas. Se trata de una decisión de vivir en la realidad. Rehuir, sutil o burdamente, la tragedia es una forma de salir de la realidad de nuestro mundo, de ser "irreales". Es caer, en la Iglesia y en la sociedad, en el antiguo docetismo cristológico - un Cristo sin realidad, ni historia-, tentación siempre recurrente: vivir en la apariencia o la anécdota.

$Y$ hay que estar claros que sin quedarse $y$ afincarse en la realidad, a nadie se puede ayudar, ni a los necesitados de fuera, ni a uno mismo por dentro. Dejarse afectar, sentir dolor ante vidas truncadas o amenazadas, sentir indignación ante la injusticia que está detrás de la tragedia, sentir también vergüenza de que hemos arruinado este planeta y que no lo arreglamos, todo ello es importante para saber ayudar en la tragedia. Y lo que es más importante, todo ello puede llevar a sentir compasión y a ponerla en práctica.

En segundo lugar, este dejarse afectar por la tragedia es también salvífico, porque nos instala en la verdad y nos hace superar la irrealidad en la que vivimos. Por ello, bien harán instituciones, sobre todo las de la palabra, iglesias y universidades, 
en analizar y proclamar la verdad de estas tragedias - y ojalá lo hagan también gobiernos, las multinacionales, los ejércitos y la banca mundial, aunque aquí las esperanzas decaen o se desvanecen, según los casos-.

En este contexto, es especialmente importante que los poderes que manejan y configuran el planeta, y los medios de comunicación, hagan "la opción preferencial por la verdad". En esto, el panorama que ofrecen los medios es muchas veces desolador. Ofrecen como noticia -escandalosa, por cierto- los millones que gana un futbolista, pero esto no pertenece a la realidad más real, sino a la anécdota factual, escandalosa y adormecedora, en un mundo que se muere de hambre. La "noticia" sólo se convierte en "realidad" cuando se comparan las cifras de lo que ganan deportistas, cantantes, estrellas de cine, con lo que cuesta reconstruir escuelas y hospitales después del terremoto, o con lo que tiene para sobrevivir un ser humano en África o en Bangladesh. Y, entonces, se aprende mucho sobre la realidad, sobre lo que es agravio comparativo, injusticia, inhumanidad. Todo ello desafía la imaginación y produce vértigo, pero, sobre todo, se convierte en interpelación inacallable: “ ¿es humano un mundo así?". Y sub specie contrarii exige repensarlo desde la familia humana.

En tercer lugar, este dejarse afectar por la tragedia puede generar solidaridad. Suele ocurrir a veces que una desgracia ayuda a unir. $Y$ es que en los seres humanos siempre hay reservas y reductos de bondad, dormidos muchas veces, pero que pueden ser activados por el sufrimiento de los otros. No somos siempre y del todo egoístas. Un terremoto en El Salvador, una hambruna en Calcuta, la epidemia del sida en África, bien pueden ayudar a generar conciencia de familia humana.

En los pueblos sufrientes, crucificados, hay algo que atrae y convoca, que nos puede llegar a sacar de nosotros mismos, y ahí está el origen de la solidaridad. Entonces, junto al sentimiento ético de obligación o junto a la superación del sentimiento de culpa, aparece lo más hondo y decisivo: el sentimiento de cercanía entre los seres humanos. Las solidaridades concretas vienen después, y buena falta hacen. Pero todo esto, su calidad, su firmeza, el "para siempre" de la solidaridad, surge de ver algo bueno y humanizante, no sólo costoso y riesgoso, en el estar cerca de las víctimas de este mundo. $\mathrm{Y}$, entonces, quizás acaece el milagro de lo humano: el llevamos mutuamente, el dar y reci- bir lo mejor que tenemos. Y el milagro mayor de queremos unos a otros como miembros de una sola familia. Los cristianos lo decimos con la mayor radicalidad: queremos como hijos e hijas de Dios. Ocure, entonces, el milagro de la mesa compartida, el gozo de ser familia humana.

El terremoto, sin saberlo, nos remite a algo central de la fe cristiana: "Jesús crucificado es el que lo atrae todo", dice Juan. El pueblo crucificado es lo que tiene capacidad para convocar, para que vengan de muchas partes y con diversos aportes, dando y recibiendo lo mejor que cada uno tiene. Mantener esa solidaridad supone un lugar y un tiempo. El lugar se define como "quedarse", en cuerpo o en espíritu, pero quedarse en verdad, seducidos por los crucificados. El tiempo se define como "para siempre", por haber descubierto una perla preciosa y un tesoro escondido.

\subsection{La santidad de vivir}

Cuánto de lo que acabamos de decir sca real hay que analizarlo con cuidado, pero es un hecho suficientemente masivo como para poder hablar de la gracia que aparece en un terremoto. Queremos terminar, sin embargo, analizando una gracia más masiva, mayor y más primigenia, que vamos a exponer en lenguaje narrativo.

El desfile de gentes, caminando o en vehículos muchas veces destartalados, con bultos en la cabeza y niños agarrados de las manos, es la expresión más fundamental de vida y del anhelo de vivir -con gran dramatismo lo hemos visto en Los Grandes Lagos- El habitante del pueblo de Armenia, totalmente destruido, que puso un solitario cartel en medio de las ruinas, "Armenia vive", expresa una esperanza indestructible. Esa vida y esa esperanza surgen de lo mejor que son y tienen los pobres. $Y$ con frecuencia no tienen mucho más.

Por experiencia secular desconfían de gobiernos, autoridades y funcionarios, aunque siempre haya entre éstos personas responsables. Los pobres saben que tienen derecho a ser asistidos y ayudados. Si llega esa ayuda, es bien recibida, y cuando no llega $-y$ pueden hacerlo- protestan, porque no les ha llegado. Pero no esperan mucho y, por ello, su reacción fundamental es otra: ponen a producir sus fuerzas y su ingenio al servicio de la vida. En medio de la injusticia se impone la fuerza de la vida y, a pesar de todo, se hace presente el encanto de lo humano. 
Y junto al impulso del propio vivir, surge también la fuerza de la solidaridad primordial. La primera solidaridad es la de los pobres, la de unos con otros. En medio de ruinas reparten lo poquísimo que les ha quedado, y a veces los ejemplos son más conmovedores. En La Colina no había a mano muchas excavadoras mecánicas para desescombrar y, además, hubiese sido peligroso usarlas, pues podían destrozar los cadáveres. Entonces, largas hileras de hombres, pasándose baldes de tierra de mano en mano, se pusieron a remover miles de metros cúbicos de tierra. Pasaron los días y siguieron buscando cadáveres, esperando el milagro de algún cuerpo que todavía estuviera con vida. Es la fuerza primigenia de la solidaridad: buscar a otros seres humanos, para hallarlos vivos o para enterrarlos — con dignidad-, si son encontrados muertos.

$\mathrm{Y}$ en esa solidaridad primigenia siempre e indefectiblemente está la mujer como referente universal de solidaridad: cuidando a los niños entre escombros, haciendo $y$ reparliendo lo que haya de comida en los campamentos de damnificados, animando siempre, sobre todo, con su presencia, sin claudicar, sin cansarse. Es como el referente úllimo de vida, que no defrauda. La mujer siempre está en medio de la catástrofe y siempre está promoviendo la vida.

Me gusta pensar que en esa decisión primaria de vivir y dar vida aparece una como santidad primordial, que no se pregunta todavia si es libertad o necesidad, virtud u obligación, gracia o mérito. No es la santidad de las virtudes heroicas —exigidas en canonizaciones-, sino la de una vida realmente heroica. No sabemos si estos pobres que claman por vivir son santos intercesores o no, pero tienen fuerza para mover el corazón. Pueden ser "santos pecadores", si se quiere, pero cumplen insignemente con la vocación primordial de la creación: ser obedientes a la llamada de Dios a vivir y dar vida a otros, aun en medio de la catástrofe. Es la santidad del sufrimiento, que tiene una lógica distinta, pero más primaria, que la santidad de la virtud.
Algo semejante escribimos hace años sobre las mayorías masacradas en tiempos de represión, a las cuales no se les suele llamar "mártires" - y ni nombre tienen-. Y pensamos que esas reflexiones siguen teniendo importancia actual, en tiempos de terremoto ${ }^{12}$. Si hacemos un ejercicio sobre qué es la santidad primigenia, comparándola con la de Jesús, quizás pudiéramos decir lo siguiente. Comparadas sus muertes con la de Jesús, reflejan menos el carácter activo de lucha contra el antirreino y expresan menos la libertad de Jesús. Pero por olro lado, expresan más la inocencia histórica, pues nada han hecho para merecer la muerle más que ser pobres, y expresan más la indefensión, pues ni posibilidad física tienen para evitar la muerte. Y sobre todo, expresan mejor que son esas mayorías las que cargan injustamente con un pecado que las ha ido aniquilando poco a poco en vida $y$, definitivamente, en muerte. Se las llame o no mártires a estas mayorías oprimidas en vida y masacradas en muerte, ellas son las que mejor expresan el ingente sufrimiento del mundo. Son los que, sin pretenderlo, sin desearlo y sin saberlo, "completan en su carne to que falta a la pasión de Cristo".

Ante las víctimas pienso a veces que para poseer las virtudes que suelen requerir los procesos de canonización hay que pertenecer ya a un estrato socioeconómico que las haga posibles. Sea de esto lo que fuere, creo que hay que repensar la noción misma de santidad, y no para añadir precisiones canónicas, sino para dar cabida al hecho mayor de la santidad primigenia. Los pobres, víctimas de la injusticia cotidiana, de terremotos o de represión, creemos que participan de una santidad de orden distinto, cuasi-metafísico, podriamos decir, en su elemental trabajo y esperanza por dominar simplemente la vida. Quizás ante ellos podamos repetir lo que dijo el centurión ante Jesús crucificado: "verdaderamente éstos son hijos e hijas de Dios".

\section{Dónde estaba Dios}

Quinta proposición. En el terremoto Dios está escondido y sufre en silencio con las victimas.

12. Cfr. Jesucristo liberador (San Salvador, 200)1, 4º ed.), pp. 450ss. 
Pero la esperanza no muere y en ella sigue presente, misteriosamente, Dios.

En El Salvador proliferan muy diversos tipos de religiosidad, pero en su conjunto es un país religioso, y más en estos días de catástrofe. De ahí que se haya hablado mucho de Dios y de formas muy distintas, incluso contradictorias. Veamos en tres pasos qué podemos decir de Dios y qué no podemos decir.

\subsection{La aberración: el terremoto como castigo de Dios}

Hay cristianos, de diversos grupos y confesiones, fanáticos y tremendistas, que asustan con profecías de catástrofe y anuncios del fin del mundo, lo cual suele ocurrir con ocasión de eclipses, cambios de siglo... Ahora responsabilizan a Dios del terremoto. Este habría sido castigo de Dios por los pecados de los hombres - también en el terremoto de Guatemala, en 1976, el arzobispo de entonces dijo que la causa eran los pecados de los sacerdotes-. Este mensaje es injuria a Dios y daño injusto a los hombres, pues aumenta la angustia "espiritual" de quienes viven ya en anguslia "física" por la destrucción y en angustia "psíquica" por la inseguridad - lleva ya seis semanas temblando-.

De todas formas, teniendo en cuenta que mucha gente se deja impresionar por esta visión de Dios, digamos brevemente lo siguiente. Es cierto que en pasajes legendarios del comienzo de la Biblia se dice: "Viendo Yahvé que la maldad del hombre cundía en la tierra, y que todos los pensamientos que ideaba en su corazón eran puro mal de continuo, le pesó a Yahvé de haber hecho al hombre en la tierra, y se indignó en su corazćn. $Y$ dijo: "voy a exterminar de sobre la haz del suelo al hombre que he creado"' (Gen 6, 5-7). Estas palabras dejan de tener sentido hasta el día de hoy, pues expresarían la irritación de Dios ante un mundo cruel, que genera pobreza, injusticia, desprecio y muerte para muchos millones de seres humanos. Pero nada tiene que ver con el terremoto y mucho menos con las víctimas y su sufrimiento.

En primer lugar, hay que recordar que Yahvé sí envió el diluvio como castigo, pero salvó de él a Noé y, sobre todo, tras el diluvio, juró que no volvería a destruir su creación, sino que haría una alianza con los hombres. El arco iris es la señal de esa alianza. Desde entonces, y a lo largo de toda la escritura, Dios aparece siempre como fiel a los seres humanos. No maquina su destrucción, sino que quiere que tengan vida. En Jeremías habla de la nueva y definitiva alianza (Jr 31, 31-34). Y Jesús resume su actividad diciendo: "he venido a traer vida y a que la tengan en abundancia" (Jn 10, 10). Es absolutamente falso que Dios quiera destruir su creación por causa del pecado. Quiere la conversión, la de los opresores y poderosos sobre todo, que cambien los corazones de piedra en corazones de came. Para ello envía profetas y, finalmente, a Jesús.

En segundo lugar, hay que recordar que las víctimas del terremoto no son simplemente "seres humanos pecadores", sino que son, en su gran mayoría, pobres. Si algo dice la Biblia con absoluta claridad es que Dios ama y defiende al pobre, a quien el poderoso "vende por un par de sandalias" (Am 8, 6), al que "está postrado ante la mesa del rico Epulón esperando a que le caigan migajas" (Lc 16, 20-21). En favor de estos pobres, Dios ha hecho una opción primigenia y fundamental. El salmista dice "Padre de huérfanos y viudas eres tú" (Sal 68, 6). Confiesa que "la esperanza de los pobres no perecerá" (Sal 9, 18). La confesión de fe de Israel se concentra en estas palabras: "En ti el pobre encuentra compasión". Dios es un Dios de los pobres, no contra los pobres, aun con sus fallos y pecados.

Por último, Jesús anuncia la venida del reino de Dios para los pobres de este mundo: los encorvados por el peso de la vida, los despreciados y marginados, los que no lienen palabra y no son tenidos en cuenta. De ellos dice Jesús que es el reino de Dios, y por defenderlos de sus opresores llegó a morir en una cruz.

Este amor de Dios a los pobres, por el mero hecho de serlo, ha producido lo mejor y más profundo de la tradición cristiana. "Del más chiquito Dios guarda memoria", dice bellamente Gustavo Gutiérrez, recordando a cristianos del tiempo de la colonia. Los obispos dijeron en Puebla que "por el mero hecho de ser pobres, independientemente de su condición personal y humana, Dios los defiende y los ama" (Puebla, 1142). Y Monseñor Romero echó su suerte con ellos: "No quiero seguridad mientras no se la den a mi pueblo". El Dios de Jesús es implacable con el opresor. Pero es el Goel del pobre, su defensor, su vengador. No les envía terremotos.

\subsection{En el terremoto está el Dios escondido}

La mayoría de los cristianos no reacciona como los fanáticos tremendistas, aunque muchos de 
ellos tengan que sufrir sus prédicas. Se dirigen a Dios con agradecimiento: "gracias a Dios estamos vivos"; con esperanza: "primero Dios saldremos adelante". Y con sumisión para encontrar algún sentido en la catástrofe: "que se haga la voluntad de Dios". Son frases cercanas a otras típicamente salvadoreñas: "primero Dios", es decir, "sólo Dios puede ayudar, de los hombres no podemos esperar mucho". O esta otra, menos religiosa, pero que apunta también a cómo comprenden los pobres el sentido de la vida: "a saber". Es decir, en la realidad no hay mucha lógica que haga el futuro predecible, ciertamente no una lógica que esté a su favor.

Esta reacción religiosa es comprensible por la cultura tradicional y por la necesidad actual para encontrar sentido en medio del dolor y del absurdo. Bien visto —en fría lógica- no faltará quien se pregunte si agradecemos a Dios por estar vivos y en nuestras casas, ¿qué pueden decir a ese mismo Dios los muertos y los que se han quedado sin casa? Aunque la religiosidad tradicional lo intente, no es tan sencillo mantener a Dios distante de la tragedia.

Esto es lo que en la tradición ha llevado a la pregunta de la teodicea: “ ¿es Dios bueno, es poderoso?". La gente sencilla apenas si pronunciará estas palabras, pero son razonables y, en sí mismas, no tienen nada de irreverentes. Se trata simplemente de preguntarse por Dios, lo cual los seres humanos hacen de vez en cuando. Más específicamente, se trata de preguntarse dónde estaba Dios en el terremolo. $Y$ no es malo hacer esas preguntas, pues, en definitiva, nos pueden llevar a un conocimiento y a una fe más profunda en Dios.

Así ocurría durante "el terremoto" de la guerra. Un sacerdote europeo que estuvo en Morazán, zona muy sufrida por la represión y la guerra, se preguntaba cómo es posible que el pueblo que había pasado por todo, bombardeos, desaparecidos, asesinatos, masacres, nunca se quejase de Dios. Al contrario: "Ayer tuvimos un bombardeo y nos salvamos por Dios [...] Dios actúa, padre [...] Dios está con nosotros, padre, porque si no hubiera es-

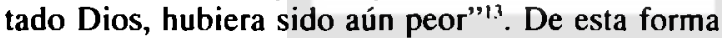
expresan su fe en un Dios salvador y con poder.

Pero a veces, las cosas no son así, y aparece un segundo momento. Comprensiblemente, el sacer- dote citado, que por su origen y formación ha pasado por la ilustración, decía después de la masacre de El Mozote:

Más de mil campesinos asesinados. No exagero. Yo vi muchos de los cadáveres mutilados, deshaciéndose. Días después se sentía aún un olor insoportable. Las casas destruidas, todos muertos [...] Cuando miré las pilas de los muertos, la destrucción, no pude aguantar. ¿Cómo es posible que precisamente aquí, a donde he llegado lantas veces para decir que Dios es un Dios cercano y que nos quiere, que no queda indiferente ante el dolor, que precisamente aquí suceda una masacre tan espantosa? ${ }^{14}$.

Y no sólo el sacerdote, sino también los campesinos se hacen la misma pregunta. "Cuántas veces no decimos que Dios actúa en nuestra historia [...] Pero, padre, y si actúa, ¿cuándo acaba esto? ¿Y lantos años de guerra y tantos miles de muertos? ¿Qué pasa con Dios?”'15.

Ya hemos dicho que éstas no son las preguntas más normales entre la gente sencilla, pero tampoco hay que ignorarlas absolutamente. $Y$ para ello hay dos razones importantes.

Una está tomada de la entraña del evangelio. La oración de Jesús en el huerto y su muerte en la cruz muestran a un Dios silente, inactivo. La tradición pone, sin empacho, en boca de Jesús el grito "Dios mío, Dios mío por qué me has abandonado". Entonces, si Dios estaba en la cruz de Jesús, no es el Dios en que solemos pensar. O por decirlo de olra manera, a su poder en la creación, en el éxodo, en la resurrección, hay que añadir ahora su impotencia y silencio en la cruz. Esto sucle ser una sorpresa, posiblemente la mayor sorpresa por la que pasa el ser humano religioso, pero ayuda muy importantemente a profundizar en el misterio de Dios, a no trivializarlo, a no considerarlo como uno de los poderosos "santos" del cielo — aunque, indudablemente, sea el mayor-, que nos puede salvar con milagros. Dios no es así.

El Nuevo Testamento, haciendo de la necesidad virtud, dirán algunos, pero, más de fondo, diciéndonos la última palabra sobre Dios, dice que Dios estaba en la cruz de Jesús reconciliando al mundo $(2 \operatorname{Cor} 5,19)$. Y, precisamente, en esa cruz

13. María López Vigil, Muerte y vida en Morazán (San Salvador, 1989, $3^{3}$ cd.) p. 119.

14. Ibid., pp. 94 ss.

15. Ibid., p. 119. 
en la que está silente, Dios muestra su amor: "tanto amó Dios al mundo que envió a su hijo" (Jn 3, 16), "cuando todavía éramos pecadores Cristo murió por nosotros" $(\operatorname{Rm~} 5,8)$. No es fácil entender, pero al menos hay que estar claros en lo que quiere decir el Nuevo Testamento: Dios muestra su amor al hacerse cercano a las víctimas, al hacerse solidario con ellas totalmente y hasta el final.

La segunda razón tiene que ver con esta afirmación del Nuevo Testamento, pero vista ya desde nuestro mundo. Los pobres y las víctimas quieren, sin duda, un Dios que no sea como ellos, es decir, que tenga poder para salvarlas. En términos técnicos, los pobres de este mundo quieren que en Dios haya alteridad, diferencia con respecto a ellos. Lo mismo ocurría con monseñor Romero o Ignacio Ellacuría: los pobres los querían distintos, con el poder de la palabra y de la institución eclesial, con el poder de la razón y de la institución universitaria, que aquéllos tenían y del que ellos carecían. Pero no es ésa toda la verdad. Cuando monseñor Romero rechazaba la seguridad personal —se empobrecía, se hacía vulnerable- para correr los mismos riesgos que el pueblo, cuando Ignacio Ellacuría regresó de España, el 13 de noviembre de 1989, para estar presente en medio de la ofensiva, los pobres sintieron cercania, y en ello encuentran salvación. En lenguaje técnico sienten afinidad.

Volvamos a Dios. Los pobres se dirigen a Dios para que los salve con su poder, y ven en ello el amor eficaz. Pero también se dirigen a Dios cuando lo encuentran cercano a su propio sufrimiento, y en ello ven un amor creible. En plena tragedia de la segunda guerra mundial, decía Dietrich Bonhoeffer:

Dios, clavado en la cruz, permite que lo echen del mundo. Dios es impotente y débil en el mundo, y sólo así está Dios con nosotros y nos ayuda. Sólo un Dios que sufre puede ayudarnos ${ }^{16}$.

La pregunta sigue resonando: "dónde está Dios". También la hizo Jesús y Pablo tuvo la audacia de responder: "en la cruz". Cuentan que después de los horrores de Auschwitz, alguien pre- guntó con indignación comprensible: “ ¿y dónde estaba Dios?". Y alguien contestó con indefensa serenidad: "Dios estaba en Auschwitz". También lo hemos oído estos días: "Dios está en EI Cafetalón" con los damnificados.

\subsection{El Dios de la esperanza}

La pregunta más decisiva, sin embargo, no es dónde, sino cómo está Dios en medio de la catástrofe. La respuesta puede ser filosófica o poética, resignada o de protesta. Desde la fe cristiana, Dios está en la cruz, generando esperanza. Esto es fe evidentemente, pero no hay que ignorar que esa cruz ha desencadenado, a lo largo de la historia, mucho compromiso, mucha justicia y mucho amor - así como ha generado resignación y desentendimiento de las víctimas-. Y en el culmen de la paradoja cristiana, ha desencadenado también mucha esperanza.

En estos días se repite el escándalo de la esperanza que nace de la cruz, y como esperanza histórica. Para ilustrarlo, terminemos con la siguiente anécdota. Con el terremoto han quedado destruidas varias iglesias, entre ellas la iglesia de El Carmen, en Santa Tecla. Con dolor le decía la gente al párroco "Padre, nos hemos quedado sin iglesia". Y el párroco, Salvador Carranza, les contestó: "Nos hemos quedado sin templo, pero no sin Iglesia. La Iglesia somos nosotros y de nosotros depende mantenerla con vida". Hace años, en tiempo de represión y guerra, decía monseñor Romero: "El día en que las fuerzas del mal nos dejaran sin esta maravilla [la radio], sepamos que nada malo nos han hecho. Al contrario, seremos entonces más 'vivientes micrófonos' del Señor y pronunciaremos por todas partes sus palabras" (Homilia del $27 \mathrm{de}$ enero de 1980).

Estas palabras son retóricas, pero son lúcidas y verdaderas. Expresan esperanza y anhelo de solidaridad. Apuntan, desacostumbradamente, a lo fundamental. La mayor tragedia es la destrucción de lo humano de un pueblo. La mayor solidaridad es ayudar a reconstruirlo. La mayor esperanza es seguir caminando, practicando justicia y amando con ternura. ¿Ha muerto esio en El Salvador?

16. Resistencia y sumisión (Barcelona, 1971, 2ed.) pp. 21(0ss. 
Creemos que no, pero hay que hacerlo crecer. En este sentido, ojalá la solidaridad ayude a reconstruir casas, pero sobre todo personas, pueblo; ayude a reparar caminos, pero sobre todo modos de caminar en la vida; ayude a construir templos, pero sobre todo pueblo de Dios. Ojalá la solidaridad dé esperanza a este pueblo.

Y mientras esto siga ocurriendo podrá haber seres humanos que, en medio de terremotos y catástrofes, sientan una fuerza mayor que los mueve a la solidaridad y a la esperanza. Sin cambiar "milagreramente" la realidad, esa fuerza siempre está dispuesta a construir la realidad y una realidad más humana. A esa fuerza, con temor y temblor, la llamamos "Dios". Y podemos decir: "Dios estaba en el terremoto manteniendo la esperanza".

Es la esperanza que siempre mantuvo monseñor Romero y que siempre ofreció a los demás. En estos días resuenan sus palabras: "Sobre estas ruinas brillará la gloria del Señor".

San Salvador, 21 de febrero de 2001. 